[綜説]

\title{
白内障の病理と治療
}

日本医科大学眼科学教室 小 口昌 美*

\begin{abstract}
緒言
水晶体疾患は先天異常として水晶体欠損, 円錐水晶 体などがあり，位置異常としては偏位，脱臼がある。 さらに白内障があり先天, 後天いずれもかなり頻度が 高い。白内障は水晶体が溷濁した場合の名称で, 先天, 後天, 原因, 症状のいかんを問わずいずれも白内障と 呼ぶ。老人性白内障は最も頻度が高く, 症状が進行し た場合には盲にも到るため吾人の関心の的である。し たがってその病理成因と治療については古来より膨大 な研究業績があってすべてを網羅することは全く不可 能に近い。古代ローマの医学に白内障の記載があり, すでにその病理治療が述べられ，また遠く古代インド の紀元前 6 世紀に白内障は成熟するのを待って手術す べきであると明記されているといら。近年は成因につ いては生化学的立場より解明しようとする傾向が盛ん になった。しかし一方従来より研究されてきた解剖生 理学方面の研究も今後の重大目標の 1 つであらねばな らない。この両者相俟って白内障の病理治療は解決さ れなければならない。題目のとおりの全般について整 理記載する余裕もないのでここでは主として教室関係 の研究を中心にして白内障病理および治療について記 述する。
\end{abstract}

\section{1. 水晶体付近の解剖}

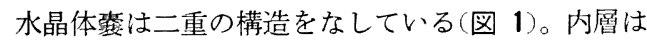
エオジンで赤く染まり, 水晶体線維の産生物である。 外層洼アザン染色で青く染まり小帯薄板とも呼ばれ る。小帯薄板はチン氏帯の延長である。すなわち，小 帯薄板が水晶体の外層を包んでいることになる。

チン氏带は無㩐造無核の硝子様線維より成ってお り，毛様体の透明上皮の延長である(図 2)。透明上皮 が毛様体内境界物をつくると同時にチン氏帯の線維と なり水晶体を小帯薄板として包んでいる。チン氏帯は

* 教授

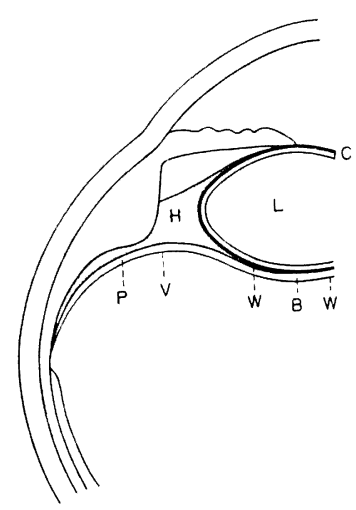

図 1

$\mathrm{L}$ : 水晶体 陰影部チン氏带, $\mathrm{V}$ : 硝子体膜, $\mathrm{H}$ ：ハノーバー氏管, $\mathrm{P}:$ : プチー氏腔, W : ウィーガ氏 硝子体 (水晶体靱带), $\mathrm{B}$ : ベルゲル氏腔, $\mathrm{C}$ : 水晶体整 外層は小带薄板, 内層は水晶体線維の産生による。

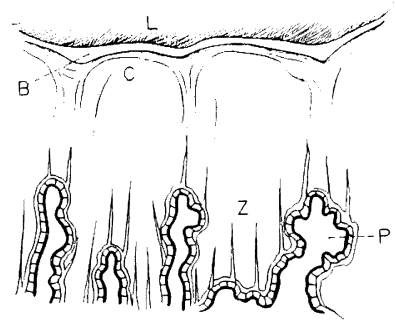

図 2

$\mathrm{L}:$ 水晶体, C: 小帯薄板, $\mathrm{Z}:$ チン氏带, B : 水晶体翼の 天幕状隆起, $\mathrm{P}:$ 毛様体突起

線維成分の間にセメント様物質を満している。図 2 を みると毛様体透明上皮が線維様に延びて内境界膜を作 くると同時にチン氏帯線維として水晶体に向っている ことが明らかである。チン氏帯は図 3 のごとくに，1 つの continuous の膜様組織である。水晶体赤道部に 近いチン氏帯の内腔はハノーバー氏腔と呼ばれる。八 ノーバー氏腔の真の存在については現今においても疑 う学者がある。 


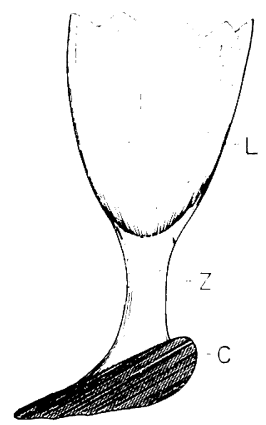

図 3 ウシのチン氏帯横断面, 生の標本 (Duke-Elder)

$\mathrm{L}$ : 水晶体, $\mathrm{Z}$ : チン氏帯, $\mathrm{C}$ : 毛様突起

Goldsmith") はこの問題に解決を与えハノーバー氏 腔の存在と，その意義を明らかにした。Goldsmith は ハノーバー氏腔よりセメント様物質を取出し一種の膠 質液であるとし，この膠質液の変化が白内障の成立の 重要な要素であるといった。

チン氏帯は水晶体の後極にも及び, 後極の種々の病 的変化に参与する。水晶体後極と硝子体との間をベル ゲル氏腔と呼ぶことがある。そこにウィーガー氏硝子 体水晶体勒帯がある(図 1)。これは水晶体と硝子体を 軽く結合させている。この勒带はチン氏带線維と同じ く硝子様, 無核の線維である。水晶体後極の栄養にも 密接な関係があると考えられる。併発白内障によくみ られる後極の変化はチン氏帯ベルゲル氏腔, ウィーガ 一氏勒带などの変化を頭におくとよく理解することが 出来る。

\section{2. 水晶体の発生}

水晶体は表皮性外胚葉がくびれて陷入し, それを神 経性外胚葉が取囲むようにして眼球が形成されるので ある(図 4)。表皮性外胚葉の延長が続いている間は問

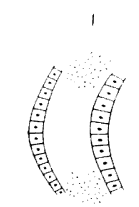

4

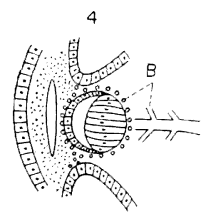

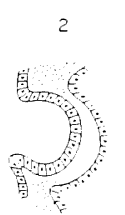

5
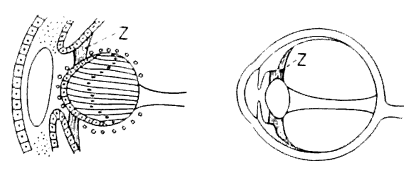

図4 水晶体の発生

B：血管，Z：チン氏带，C：前房
題はないが，その連続が断絶される時期になると中胚 葉性の血管が水晶体を取囲む形になる。この時期から の水晶体はこの血管膜により栄養されるようになる。 水晶体血管膜は後方の硝子体動脈より, 前半は虹彩動 脈より形成される。

水晶体麗は始めは血管系により形成されるようにみ える。胎生 3 力月になると前房の形成も始まり, 毛様 体側よりチン氏帯が延びてゆく。チン氏帯が水晶体に 達し，小帯薄板の形成に参与する。胎生 5 力月の眼球 をみると前房も十分に発達しチン氏帯も完成に近い。 毛様突起もよく発達し突起の数が増加してくる。

この時期の水晶体は水晶体血管膜とチン氏帯に囲ま れ，前房との関係は全く間接的である。胎生 7 力月に 至るとほとんど新生児の眼球に近くなる。すなわち， 水晶体血管膜が漸次消失し水晶体はチン氏帯で毛様体 と後方はウィーガー氏靶帯で硝子体と連絡する。水晶 体血管膜は出産までかなり残ることが多いとされてい る。瞳孔膜遗残が相当に多いのはこのためである。す なわち, 水晶体血管膜は出産まで水晶体と連絡し, 水 晶体の栄養に関係していると考えられる。生後の連絡 はチン氏帯拉よ゙ウィーガー氏勒帯のみとなる。この 両者主としてチン氏帯が水晶体と連絡されるのであ る。

胎生期の前房の発達は 3 力月前後に始まり, 5 力月 では相当進行し胎生 7 力月で完成に近い。ところがこ の時期に至るも水晶体を取巻く血管が残っているのは 相当有意義のことで前房水と水晶体の関係は栄養の点 においてはあまり意義がないようにみえる。

\section{3. 水晶体の系統発生}

水晶体を有する眼球を水晶体眼と呼ぶ。脊椎動物は 円口類に始まり哺乳類に至るまですべてカメラ眼であ る。カメラ眼の始まりは杯状眼であると考えられる が，この杯状眼に水晶体のついたものがカメラ眼であ る。杯状眼は腹足類のアワビなどにみられる。

カメラ眼は脊椎動物の一致した形態であり，レンズ により太陽光線を集中するので視細胞に明確な像をつ くるのである。カメラ眼は環形動物にもみられるとい らが, 興味深いのは軟体動物のうち頭足類 (タコ, イ カ) のカメラ眼である(図 5)。

脊椎動物の眼球に比較して, その構造の要点は全く 同様である。尙椎動物とは全くその采統を異にする頭 足類の眼球がわれわれ哺乳類と似ているのは興味が深 い。この現象を収㪘進化という。タコの眼は瞳孔を備 


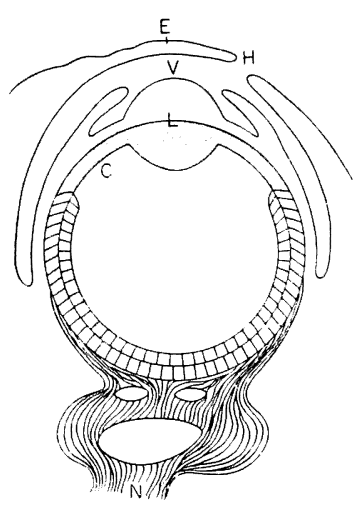

図 5 タ コの眼球

L : 水晶体陰影部は毛様体の延長上半は虹彩の延長を示 す, $\mathrm{E}$ : 表皮 (角膜), $\mathrm{H}$ : 開孔（涙孔）前房と海水流 通寸, $\mathrm{V}$ : 前房, $\mathrm{I}$ : 虹彩, $\mathrm{C}$ : 毛㥞体, $\mathrm{N}$ : 視束

え水晶体があり，この移動によって遠近調節も出来る のである。色覚の存在も証明されるという。水晶体の グルタチオン $(\mathrm{GSH})$ を調べたところ脊椎動物のそれ と全く同様に高濃度に証明することが出来た。ヒトの 水晶体は水晶体茝垂線維により支持されているが，夕 コの水晶体は前半は虹彩の延長であり, 後半は毛様体 の延長から構成されている。すなわち, 㲘垂勒帯その ものは虹彩, および毛様体で水晶体が球体を形成する にいたって急に透明となっている。したがって水晶体 の栄養は虹彩毛様体と全く同じく開放血管系であるが 虹彩および毛様体を通して栄養されているのは明らか である。角膜は表皮そのもので透明となっている。頭 足類は角膜縁に近く涙孔がある。この淚孔を通して海 水と前房は流通している。この点は前房水の役割を理 解するのにきわめて重要である。韭椎動物のうち高等 な類はシュレム氏管から房水は眼球外に排出され, 下 等なものはシュレム氏管を欠くも同様な機構によりや はり眼球外に排出される。あたかも頭足類の涙孔は七 トのシュレム氏管のごとく房水を眼球外に排出してい るのである。頭足類はその前房が海水と流通している ので, 時に水晶体は海水で洗われていることになる。 この場合頭足類の前房水は水晶体の栄養に関係してい るとは考えられない。頭足類の前房は (1) は外傷が水 晶体に及ばないように，すなわち水晶体の保護であ る。（2）は水晶体の代謝産物の 1 部は房水に入り, 眼 球外に運ばれる。(3) 注水晶体の移動につごうよいよ うにして調節を行なうためである。水晶体と角膜と接 触していると考えるときは両者はたがいに損傷をきた しやすいし, 調節作用も十分出来ない。ヒトの水晶体

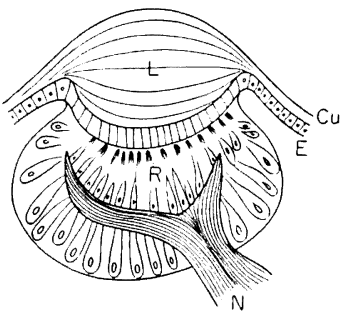

図6クモの単眼

$\mathrm{L}:$ 水晶体, $\mathrm{Cu}$ : 表皮, $\mathrm{R}$ : 網膜,

$\mathrm{E}:$ 上皮細胞, $\mathrm{N}$ : 視神経

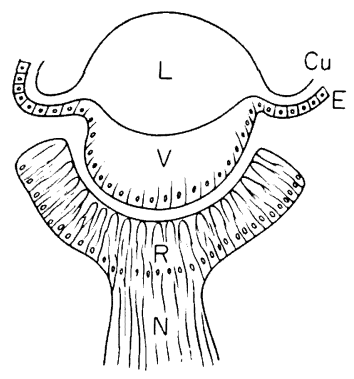

図 7 八工の単眼

$\mathrm{L}$ : 水晶体, $\mathrm{Cu}$ : 表皮, $\mathrm{E}:$ 上皮細胞,

$\mathrm{V}$ : 硝子体, $\mathrm{R}$ : 網膜, $\mathrm{N}$ : 視神経

と前房の関係も全く同じ考えが成立することは明らか である。カメラ眼以外で水晶体を有している動物は非 常に数が多い。アメーバは細胞自身が光に対して感受 性を有しておるが, 進化するにしたがい光の受容器は 局在的になってくる。ミドリムシは受容細胞が肥厚し て太陽光線を集中するように働くレンズがある。しか しこれらは水晶体として区別されてよいかどうか疑問 である。進化が進み節足動物はいずれも水晶体眼を有 している。昆虫の複眼も, またクモ類の単眼も水晶体 を有している(図 6,7)。青八エの単眼は表皮が肥厚し て水晶体を形成している。家クモのそれも全く同じで ある。脊椎動物の水晶体が表皮性外胚葉から出発して つくられた機構と異なるところがないのは興味梁い。 節足動物の水晶体は表皮の延長であり，また頭足類の 水晶体は虹彩および毛様体の延長である。脊椎動物の 水晶体は表皮性外胚葉より生じ，胎生期は血管系によ り栄養され，それ以後はチン氏帯を唯一の支持組織と して毛様体に連絡している。生物の栄盖経路の機構に 例外はないと考えればチン氏帯は水晶体に対する栄盖 経路と考えるのは当然である。下等動物の水晶体から 高等動物の水晶体にいたるまで房水中に浮んでいるご とく表現されるものは皆無である。 


\section{4. 水晶体および角膜の栄養の比較}

白内障の成立を理解するにはまず水晶体の栄養につ いて研究しなくてはならない。水晶体の栄養について はもっぱら房水, および硝子体よりとするいわゆる房 水説が支持を受けている。したがって水晶体露の透過 性が研究の対象とされる場合が多い。水晶体霰は生物 膜の透過性の実験によく使用される。しかし取出した 水晶体露の透過性の実験成績をただちに生体の水晶体 露の透過性として承認することは危険である。

「埌司氏眼科診療の実際」には水晶体は, 胎生時は血 管膜の血管から栄養されているが，生れてからこれ等 血管が消失するので周囲の体液, すなわち眼房水, 硝 子体から栄養される。水晶体と眼内液との物質交換の 機序については単純の濾化作用では説明困難で, 渗透 作用, 抗散作用も論じられているが未だ不明の点が多 いと記載されている。また Adler の眼生理学には生 れてから血液の供給がないので栄羛素と老廃物の移行 は水晶体と房水の間で行なわれると書いてある。いず れにしても従来の記載はいずれも水晶体が，房水に浮 游しているからとの表現は誤解のおそれがある。チン 氏帯の存在を忘却していると考えられる。チン氏帯を 単に支持勒帯とのみ考え, 調節作用に必要であり, ま た白内障蝍内摘出にチン氏帯の研究は必要であるとの 表現は偏見であると断じたい。チン氏帯が胎生期の水 晶体血管膜にとって替った組織であることは, 水晶体 の発生の項で述べたし, また水晶体の栄養径路である ことは采統発生の項でも比較して述べたのでチン氏帯 は単に䯚垂支持調節に関倸するのみならず水晶体の栄 養径路として重要であることは理解出来る。チン氏帯 を染色してみると膠原線維様の性質を有している。ま た横紋様構造も似ている。そしていわゆる cement 物 質が基質をなしている。近年, 生化学的の立場から は, 結合織のいわゆる cement 物質は酸性多糖類, 蛋白質, 不溶性コラーゲンなどが主成分であって, 結 合織の物質の交流の場にあたるとされている。Goldsmith もハノーバ氏腔の基質が一種のコロイドである ことを証明し，このコロイドの変化が白内障成因の initiator であることを述べたのは卓見である。チン氏 帯の基質の研究はいまだ未解決の点が多いのであるが おそらく膠原線維の基質に近いものであり，生化学的 な役割は上述のごとき物質交流の場であり, 水晶体の 栄養に重要な関係あることはたしかであると考えられ る。視器注透光体および感覚受容器である網膜がその 生命であるが, 透光体のうちで水晶体とともに重要な
役割を有しているのが角膜である。角膜も透明組織と いら点で問題になる。血管のない組織として水晶体同 様にその栄盖，物質交流が研究の対象になっている。 ここで両者を比較してみるのは有意義であるので，角 膜の栄垍に対して触れてみたい。ここで権威ある成書 の記載を引いてみよう。日本におけるものは (1) 結膜 および上琗膜をへて角膜に向う血管は輪部において边 縁血管締係網をつくり角膜内に進入しない。したがっ て角膜の栄養は主として輪部ではこの辺縁血管締倸 網，表層は涙液，後層は前房水によって行なわれる。 角膜の上皮や内皮は種々の電解質や非電解質に対して 選択的透過性をもっている。(2) 角膜は血管を欠く， 角膜の栄羑は周辺部は辺縁の血管から, 中央部は前房 水から供給される。表層の栄養には涙液も関係すると いら。(3) その栄堒は主として边縁血管締保網と房水 から行なわれている。外国の成書では (1) 角膜の栄羑 は毛細血管よりの拡散により行なわれる。(2) 角膜の 栄垗はリンパ系統により準備される。(3) 3 つの経路 の可能性が考えられる, 涙, 前房水, および毛細血管網 である。しかしこの三経路の比較的重要さについては 意見の一致をみない。唯血管系と房水系からえられて いるのは承認されている。例えば前房を空気で満して も角膜の透明には変化がない。完全な角膜 peritomy も角膜に障害はない。Cogan によると角膜の大部分 は辺縁血管による。しかし上皮も内皮も涙, あるいは 前房の物質を利用するのであろら。などである。

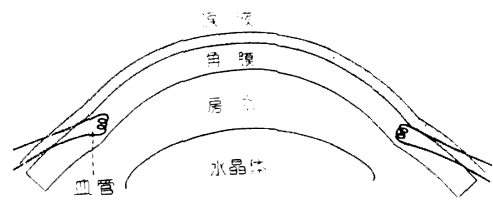

図 8 角膜の栄養経路

図 8 は角膜前房辺縁管の関係を示寸模型である。角 膜の中央部に小さい感染病䆨が出来たとしょう。角膜 辺縁血管より迅速に遊走細胞のくるのは明らかであ る。あたかも血管を伝ってくる速さにちかい。この場 合前房は始めは透明で遊走細胞などみられない。角膜 炎，または角膜欠損が角膜中央に生じた場合，その修 復作用として角膜パンヌスが出現する。角膜ヘルペス のごときパンヌスの生じがたいものは難治である。ま た角膜パンヌスが角膜中央まで進入した角膜の中央部 に空気を注入してみよう。細隙灯でみるとこの空気は 血管を伝って迅速に辺縁血管網に運ばれてゆくのがみ られる。前房なり涙液層にゆくものは皆無である。 
日本の成書の記載の根拠が奈辺にあるかはなはだ疑 問であるが，おそらく角膜の物質移行の臨床的事実や 実験から由来したものであろう。例えばアトロピンを 点眼すると迅速に前房に移行する。Neutral rot 液を 点眼しても同様にただちに前房に色素が現われる。こ れ等は涙液層を通じ角膜を貫き前房に至ったものであ る。これ等の事実を解膜の栄養経路として考えるのは 危険である。Cogan のごとく補助的役割は当然であ るが，日本の成書の記載は誤解を生じやすい危険な要 素を含んでいるといわねばならない。角膜に対して涙 液と前房水は保護的の役割と Cogan のごとく多少の 補助的役割を呈するとするのが事実であろう。例えば 涙液は結膜露に㳽漫して存在するがこれは結膜の栄養 に関与するとは考えられない。ただ眼球運動を円滑に 結膜を保護するのが目的であって，角膜に対しても同 様な関係で存在するのである。角膜も一種の生物膜で あるが，この生物膜の物質移行と栄養とを混乱させる と信頼されがたい結果を生ずるであろう。図 8 の関係 はちょうど水晶体にもあてはまり, 角膜辺縁血管網の 発達は毛様体突起の突端に集った血管䣘に匹敵するも のである。水晶体においては, 毛様体突起の血管網よ りチン氏帯を通してその栄養が行なわれるのは当然で ある。角膜, 水晶体, ともに 1 つ透明組織である。 組織であるからその細胞間隙なり, またその cement 物質が物質交流の場になるのである。角膜水晶体が無 血管組織であるからあたかも人工膜のごとき考えを適 用するのは誤解の因になる。

\section{5. 白内障の成因に関する実験}

チン氏帯が水晶体䀣垂勒帯としてのみ存在し，あま りその他の意味について検討されないのは不思議であ る。Duke-Elder も system of ophthalmology にチン 氏帯の研究は調節作用の問題と白内障の全摘出をする のに必要であるとし, やはり水晶体眯垂勒带としての 作用のみを強調している。これは偏見といわねばなら ないし，また学問としては“because they are there”, の態度が必要ではなかろうか。すなわち, organ があ るからその organ の研究が必要であって, 白内障が もし仮りに存在しないとしてもチン氏帯がある以上そ の研究は大切であり,その必要があるといわねばなら $ぬ$ ぬ

われわれがチン氏带の研究に興味を引かれたのは， GSH の研究中偶々チン氏帯にもGSHの比較的豊富に 存在することに気付いたからである。GSH は水晶体
にきわめて多量に存在し, また水晶体の透明維持に最 も関係深いことは周知のことである。これとチン氏带 の GSH と密接な関係があってしかるべきであり，チ ン氏帯が水晶体への栄養経路であることを想像したの である。そこでチン氏帯と白内障の関係を論じた文献 をあげてみよう。

1) Becker ${ }^{2)}$ はつぎのごとく述べている。

水晶体の病理に関してチン氏帯の畸形か, 病的変化 なくしては理解出来ない位である。しかし悲しいこと にチン氏帯の病理解剖は取残されている。いわゆる嚷 白内障がチン氏帯の付着部に限局していることはチン 氏帯が水晶体の栄養に特別の関係なくしては考虑出来 ない。さらに水晶体の栄養障害はその基礎における栄 養液の変化に基づくと考えられる。もちろん水晶体 が栄養物を房水より採るか，また硝子体からであるか 確定しない。しかし赤道部よりくることは考えられ る。

Becker は白内障の成因にチン氏帯の存在を重要視 しているが，水晶体の栄養については房水硝子体を取 上げている。

2) Greeff $^{3)}$ : その著書 (眼病理) につぎのごとく記 載した。水晶体の栄養の路は完全な解明は未だないけ れども水晶体の赤道部は重要であってチン氏帯の付着 点に向かって strom が流れる。Greeff の述べるごと く水晶体赤道部が水晶物の栄養液の交流に重要なこと は万人の認めることである。この赤道部は解剖の項で 述べたごとく全くチン氏帯に包まれており，液の交流 はチン氏帯を通ずる以外に方法はない。図 3をみると よくこの関係が理解出来る。また鳥類, 爬虫類の水晶 体赤道部はいわゆる annular pad と称され, 水晶体 上皮の極度に発達した部分であり，水晶体赤道部の重 要性をよく物語っている。

3) Goldsmith ${ }^{1)}$ : 白内障整内摘出研究のために千 ン氏带の研究を行なった。白内障の原因はおそらく八 ノーバー氏腔の膠質系の変化であって，こ机が水晶体 の溷濁の真の発端であろうとしている。さらに八ノー バー氏腔の液を染色して一種のコロイドであることを 証明した。チン氏帯が水晶体の栄養にきわめて関係深 いことの一事実として重要な研究である。

4) V.Kittel ${ }^{4)}$ : 後天的水晶体欠損についての報告 である。白内障とは直接の関係はないが水晶体の栄羪 を理解するのに大切な文献であるので採りあげた。氏 の経験例は幼時に虹彩切除を受けた例で虹彩欠損部の チン氏帯が一部消失し，その部分の水晶体にDelleを 
$-6-(78)$

生じたものである。氏は幼時の虹彩切除は解剖学的に チン氏帯を傷害しやすきために水晶体欠損を起すと考 えている。成人のチン氏帯離断にては Delle を生ずる ことはないが幼時の新陳代謝が盛んの時期にては水晶 体の局部的栄養障害の結果の Delle と考えられ, 実に チン氏帯の营引が消失したのも相加わって原因となっ たのであろう。Kittel は Hess, Isakowitz, van der Hoeve などの同様の報告例のあることを紹介してい る。

5) 水尾源太郎 ${ }^{5)}$ : 統計上水晶体欠損は下縁が多く, 同時に虹彩, 脈絡膜の欠損を伴なうことが多い。チン 氏帯はまれには存在するが大抵は少なくなっている か, 欠損していることが多い。水晶体の溷濁は種々で 透明のものもある。

6) 酒井信一 ${ }^{6)}$ : 先天性水晶体欠損例にてその部の チン氏帯は存在していたという。水尾, 酒井の報告の ごとく先天性水晶体欠損についての成因は種々の説が あって結論は出ない。Oettingen, Rogman のチン氏帯 説, Manz-Hess の眼裂説, Heyl の血管不給説がある。 これ等諸説のうちチン氏帯説は Becker, Rovre らの賛 成者多く, チン氏带の欠損ないし病変が欠損を招来す るとなすものである。v.Kittel の後天性水晶体 Delle 実験, またわれわれの幼若ウサギの虹彩切除により水 晶体 Delleを発生せしめた実験などからみるとOettingen のチン氏带説を最も有力な説といわ权ばならな ঋ。

7) 藤井清信 ') : 先天性水晶体偏位症の 1 例で, 13才 の患者に瞳孔膜遗残, 水晶体灰白色溷濁をみ, 瞳孔散大 して検査したがチン氏帯らしきものがみえなかった。

8) 小林紹章 ${ }^{8}$ : 水晶体発育障害の 2 例を報告し, チン氏帯の発育障害によるものならんとした。1例は 水晶体偏位で摘出水晶体は球状水晶体で直径は $6.5 \mathrm{~m}$ $\mathrm{m}$ であった。1 例は直径 $4.5 \mathrm{~mm}$ でチン氏帯の発育 異常と同時に水晶体の著明な発育障害を証明した。

以上の文献は水晶体とチン氏帯の関係を述べたもの で白内障の成因を理解するのに参考になる。われわれ はつぎのような実験を行なってチン氏帯と水晶体の関 倸を調べ, 白内障の成因解明の一助とした。

（1）ウサギおよび，ガマの頝動脈および心臓内に 色素液を注入した実験

成熟ウサギをあらかじめ部分的チン氏帯切断をして 置く。頝動脈より Neutralrot 液を多量に注入したの は図 9 である。チン氏带欠損部には Neutralrot 色素 がみられないが，その他の部の水晶体周辺に Neutral-
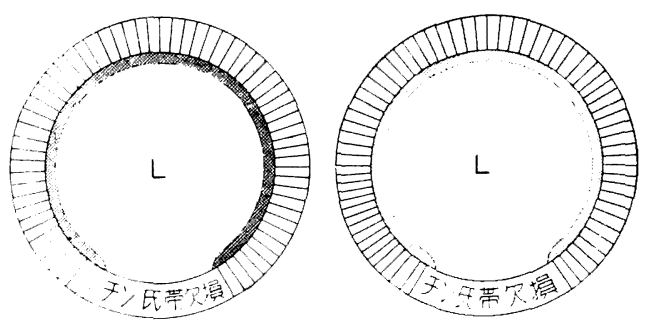

図 9 ウサギチン氏帯切断後 図10 ウサギチン氏帯切断後預 頝動脈より Neutrlrot液を動脈より Fluorescein 液を注 注入, 水晶体のチン氏带切入, 水晶体のチン氏帯切断部 断部沉は色素がみえない。にはFluoresceinがみえない。

rot が集っているのがみえる。図10 も同様に Fluorescein を注入したもので，チン氏帯欠損部には色素が みられない。前房水を洗旗し, 硝子体をよく取除き, 硝子体側より観察したもので色素がチン氏帯に入って いるのがみえる。前房側から観察しても同様の所見が みられた。これ等の実験は色素液がチン氏带を通して 水晶体に至る経過をたしかめたものである。

（2）幼若ウサギに，チン氏帯を切断し水晶体 Delle を惹起させた実験

生後 1 力月の幼若ウサギに部分的チン氏帯切断を行 なった。術後第 38 日に水晶体 Delle がみられた（図 11）。この実験は 38 眼中 34 眼に成功した。幼若ウ业 ギにては水晶体の代謝が旺盛であるので, そのさいチ ン氏帯切断は水晶体の発育に相当障害があって Delle となったものである。v.Kittel の臨床例と機転は同じ であ万う。またこの実験は先天性水晶体欠損のチン氏 帯説を支持することが出来たと思われる。

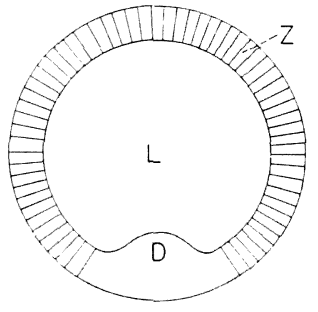

図11 生後 I 力月幼若ウサギに 虹彩切除, チン氏帯切断し 38 日後水晶体Delleを認めた。

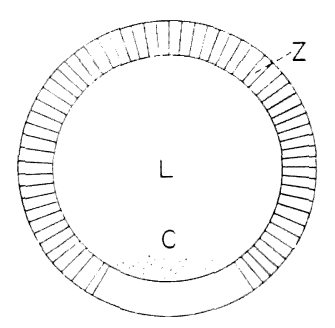

仪12 成熟ウサギチン氏带 切断部位に白内障が発生 した。
(3) 成熟ウサギのチン氏帯を切断する実験

部分的にチン氏帯を切断し 50 日後にチン氏帯欠損 部の水晶体溷濁を惹起することが出来た。1 18 眼中 13 眼に成功した(図12)。すなわち, 水晶体賟および上皮 には著変がない。溷濁部の水晶体線維はエオジンで淡 染し, 線維構造がはっきりみえない。いわゆる bladder 
cell が増殖している。白内障に普通に現われる所見 である。

（1）（3）の実験は水晶体に対しチン氏帯が物質交 流の場に当ることを証明した。そしてチン氏帯切断が 限局性の白内障，水晶体 Delle を惹起せしめたことは 先天性水晶体欠損のチン氏帯説を支持し, 白内障発生 にさいしてはチン氏帯の病的状態が主因であることを 証明したものである。もちろんチン氏帯の病的状態は 単独のものではなく, 毛様体上皮に続く変化であるこ とは十分推察出来る。赤羽” はナフタリン白内障の研 究にて, 水晶体グルタチオンの減少に比例して毛様体 上皮の GSH の減少することを発表した。われわれの 行なった実験はチン氏带切断で極端の場合のみを対象 としたのであるが，少くとも毛様体上皮の変化がチン 氏带の病的状態を惹起し水晶体に病的変化が惹起され ることは十分想像出来る。

\section{6. 白内障およびチン氏帯の臨床所見}

後天性白内障にては老人性白内障拄よび併発白内障 は白内障の病理を理解するのに対象となる。先天性白 内障は別個の立場上り観察するべきである。併発白内 障注網膜炎, 脈絡膜炎, 色素変性, 網膜剥離, 眼内腫 瘍, 葡萄膜炎, 緑内障, 水晶体脱臼などの結果として 水晶体の栄養が害されたものである。チン氏带と白内 障に関倸が比較的明らかである臨床所見をあげてみよ う。

1）老人性白内障：図 13 は老人性初発白内障の最 もしばしばみられる所見である。

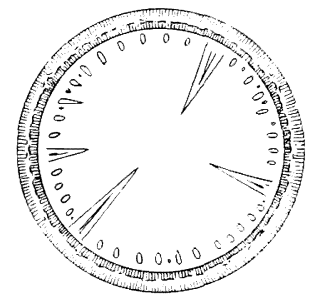

図 13 老人性白内障（初発） 楔形, 冠状, 点状の溷濁が赤道部に初発 することが多い。

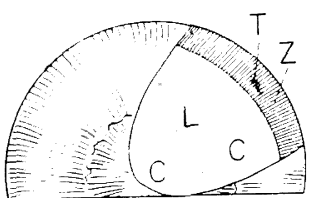

四 14 先天白内障 $L:$ 水晶体, $Z$ : チン氏 带, $\mathrm{T}$ : 溷濁, C : 白内障

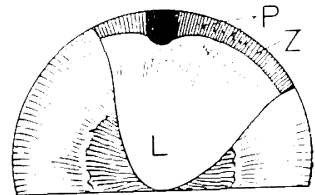

図 15 牛眼 D : Delle, P : 色素, C : 白内障, $Z:$ チン氏带
楔状, 冠状, 点状などの溷濁が赤道部にみられる。 真の意味の赤道部縁でなく，それより少し離れた個所 に並ぶのが普通である。この部はチン氏帯の線維の付 着部であり，赤道部縁には線維の付着することが少な い。この所見より何らかチン氏帯の付着部に溷濁が起 こる理由がありそうである。

2) 先天性白内障(図14)：37才女，先天性白内障の ため幼時両眼虹彩切除を受けた。外眼部には異常な く, 小眼球, 眼球振盪などはない。左眼虹彩は第 2 時 を中心に大きく切除されている。水晶体の中央部は溷 濁濃厚で眼内を徽照しない。周辺部の溷濁は淡く眼内 を徹照する。視力 0.05 である。チン氏带はやや白濁 し光沢を欠いている。チン氏带線維は肥厚し走行も多 少乱れている。右眼の所見も大略同様である。

3）牛眼 (図15)：45 才男, 幼時より両眼牛眼であ った。4才の時両眼手術を受けた。左眼は虹彩が第 12 時を中心に大きく切除欠損されている。水晶体は第 12 時近くにDelle があり，この部はチン氏帯の欠損があ る。観察されるチン氏帯はやや白濁しているが走行は 比較的正しい。水晶体は中央部が溷濁濃厚で周辺部は 比較的淡い溷濁である。視力は眼前手動, 水晶体周辺 部は赤道部に近く楔状の濃厚な溷濁がみられる。

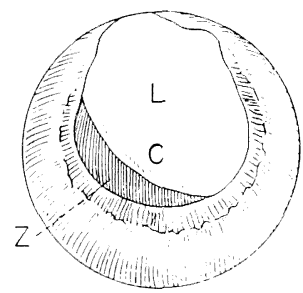

図 16 併発白内峦 $\mathrm{C}$ : 白内障, $\mathrm{L}$ : 半晶体 Z : チン氏带

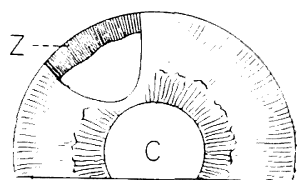

図 17 若年白内障 $\mathrm{C}$ : 白内障, Z: $\mathrm{Z}$ ン氏带
4) 併発白内障 (図16): 21 才男, 右眼は健, 左眼 は 17 才の頃から視力低下し某医によりそこひといわ れた。手術を受けて一時軽快したがその後視力はます ます低下し曈孔領が白くなったので来院。視力光覚の み, 虹彩後癒着があり瞳孔は不正円形で大きく散大し ている。水晶体は黄白色に溷濁している。瞳孔の下方 にチン氏帯が明瞭にみられる。チン氏帯線維は肥厚白 濁し走行はやや不規則である。一部のチン氏帯は波状 を呈する。

5) 若年白内障 (図17)：32 才男，数年前より視力 障害があり, 最近は右眼視力 0.1 になった。左眼視力 は1.2で健。虹彩異常なく, 瞳孔正円, 反応健。水晶 体は溷濁し眼内わずかに透見する。チン氏带検査のた 


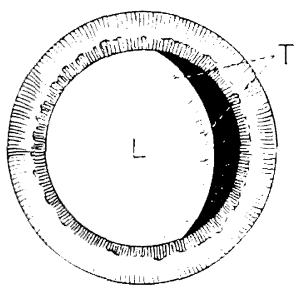

图18 水晶体脱臼

$\mathrm{L}$ : 水晶体, $\mathrm{T}$ : 白内障

め第 11 時位で虹彩切除を行なった。

チン氏帯はわずかに白濁, 肥厚す。チン氏帯線維は 点々と溷濁しあたかも絣模様に似ている。

この患者は後日白内障摘出を行ない矯正視力 1.2 を えた。

6) 水晶体脱臼, 続発緑内障（図 18）：48 才女, 1 カ月前より右眼がぼんやりしてきた。

右眼視力 $0.02(0.2 \times-6.0 \mathrm{Dcyl}-2.0 \mathrm{D} \rightarrow)$ 眼圧 $62 \mathrm{mmHg}$ 。瞳孔散大し虹彩振蕰がある。水晶体は鼻 側において脱臼し，チン氏帯はみられない。水晶体鼻 側赤道部に点状溷濁がある。左眼は瞳孔散大して検查 したが水晶体溷濁は全くない。

老人性白内障の初発症状は招打む称赤道部に起こる とが大多数である。この楔状, 冠状, 点状などの形を 説明するのに単に房水栄養説では不適当である。Becker も述べているごとくこれ等溷濁がチン氏帯の付 着部に一致していることはチン氏带が水晶体の栄養に 関係していることをよく物語るものである。ナフタリ ン白内障にても同様の初発症状が認められる。また管 錐術後に虹彩欠損部に白内障を発生しやすいことはよ く知られている。これは水晶体の外傷でなくしてチン 氏帯を傷害したためであろう。管錐術時に該部より硝 子体の漏出することがあるのは正しくチン氏帯を傷害 した証拠である。

臨床例の先天性白内障, 牛眼併発白内障, 若年白内 障のいずれもチン氏帯に病的変化を認めた。このこと は白内障とチン氏帯の病的変化と密接な関倸のあるこ とを示すむのである。もちろんチン氏帯の変化は単独 のものでなく毛様体上皮を通しての病的変化であるこ とは十分に想像される。

水晶体脱臼例の赤道部にみられた点状溷濁は脱臼の 影響か, または老人性白内障そのものであるか不明で ある。水晶体脱臼の時に早晚白内障が発生するが長く 透明を維持するものもある。

\section{7. 白内障の成因}

先天性白内障は別問題として, 後天性白内障の成因 に関しては顆しい数の学説がある。そのいずれもがそ れぞれの真理を有していることも納得出来る。したが って1つの学説ですべてを説明しつくすことも不可能 である。後天性白内障で一番問題になるのは老人性白 内障である。これは治療の対象となるからである。つ ぎに例発白内障は白内障の成立病理としては重要のも のであるが治療の対象となることが少ないので一般の 興味は薄いようである。そこで老人性白内障の成因に 関連した研究を瞥見してみよう。初期の研究は臨木的 見地から出発した。その後種々の全身疾患に相関を求 める企図がなされてきた。そのらち最も一般の注意を

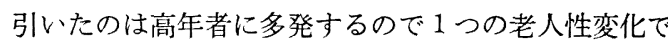
あ万うとしたのである。実際 80 才以上のもののほと んど全部に白内障があることより考えれば単なる老人 性変化とすることも可能である。しかし若年白内障な どは説明困難であるし，性腺の機能減退にその原因を 求めるものもあるが，これも老人性白内障の成因その ものとは考えられない。例えば若くして性腺を除去し た場合 (eunuchs)，特に白内障が発生するとは限らな いし，またホルモン療法も無効である。その他水晶体 の硬化㧍よび脱水を論じたものもある。Becker は老 人になると水晶体線維の硬化が不平等に起り水晶体赤 道部はチン氏帯が付着しているから核収縮の時早く分 離してまずここに溷濁が起るとした。Becker もチン 氏帯付着部の白内障初発所見に注目をしているが，こ れはわれわれの再三述べてきたチン氏帯栄養経路説の 方がより説明が合理的と思われる。

Magnus は水晶体の硬化による栄養障害とし，水晶 体の脱水のため空胞形成, 水隙形成が生じ溷濁を発生 するとした。硬化および脱水説は白内障の原因である か, 結果であるか,たしかなことは断定出来ない。そ の他の病理的変化としては毛梯体上皮の変化と水晶体 のコレステリンの増量の説がある。毛様体上皮説は実 験白内障から導かれたものである。ナフタリン白内障 にて神鳥は毛様体上皮の変化を重視し, 赤羽は毛様体 上皮の GSH の減少を指摘した。毛様体上皮の変化は 水晶体栄養に最も影響のあることは当然であって各種 の併発白内障も毛様体上皮説をもって説明出来ること が多い。コレステリン説には血液のコレステリン増量 と平行して白内障が発生し, 水晶体の脂肪沈着をみた 実験があり，老人性白内障の】つの事実とすることが 出来るが併発白内障, 若年白内障など説明することも 困難であるし，老人性白内障の成因として説明しつく 
すことは出来ない。

物理的原因としては紫外線説，赤外線説がある。柴 外線は大部分角膜に吸収される。しかし紫外線の内， 長波長の部分はわずかに水晶体に達するので白内障を 惹起する可能性はある。老人性白内障の初発溷濁は主 として水晶体の下半に始まるのは大気よりの紫外線の 影㗽と解釈することも出来る。インドに多発する老人 性白内障を単に紫外線に帰することは出来ない。

その他複雑な栄養問題も考虑せねばなるまい。赤外 線白内障は老人性白内障の説明にはならない。つぎに ホルモン説として副甲状腺, 糖尿病, 筋強直萎縮白内 障，皮膚原性白内障などがあるが，それぞれ興味ある 事実にしても一般の老人性白内障の成因としては十分 でない。

近年は化学的の業績が顆しい。これは生化学の進歩 によるもので, これには前房水の $\mathrm{pH}$ の問題, 水晶体 の酸化還元系の異常, および荻野らのトリプトファン の代謝異常説などがある。酸化還元系としてはビタミ ンCおよび GSH が白内障時には著しく減少すること が知られている。

ビタミンCおよび GSH ともに健康な水晶体にはき わめて多量に含有されている。両者とも白内障の進行 とともに減少してゅく。しかし白内障は壊血病の併発 症でもなく，またビタミンCを補給しても白内障は治 癒しない。近年 GSH の減少が白内障の原因であろう との説が多くなってきた。Pirie らのX線白内障の実 験にても GSH の水準がまず低下し溷濁の進行ととも に減少に拍車をかけることが判明した。GSH の減少 は還元酵素系の不活性化が要因と考えられている。ビ タミンCも減少するが溷濁発生との間に有意の相関は みとめがたいとされている。荻野らは肝臟機能とトリ プトファンの代謝異常に関連をもつ水晶体蛋白の変性 であるとしている。以上は老人性白内障の成因に関す る研究のうち主なものである。

\section{8. 白内障亡 GSH}

白内障と GSH の関倸は多く注目し支持していると ころである。教室にて研究したことがらのみを述べて みたい。小口, 清水 ${ }^{22)}$ は $\mathrm{GSH}$ 銅錯塩蛍光法を考案し た。この方法は組織の GSH を証明するに有力でかつ GSH に対する特異性が高い。この検出法により小口， 樋田, 清水(由), 清水 ${ }^{23)}$ は眼球各組織の GSH の分布 を調べてみた。その結果, 水晶体 GSH が最も濃厚で あることはもちろんであるが, 視束に多量の GSH を
認めた。ところが緑内障により, 失明した眼球の視束に はGSH が消失していた。さらにチン氏帯に GSH の存 在を認め,網膜内層にもやや多量の GSH を認めた。こ れ等の所見より白内障の治療に GSH を使用する端緒 ともなり,さらに網膜視神経疾患に対しても GSH 療 法を進めることになった。内山泫は実験的ガラクトー ス白内障の研究にて幼若ラッテに GSH がある程度の 白内障発生の予防的効果のあることを知った。星 ${ }^{25)}$ は 幼若ラッテに GSH 前処理後X線照射を行ない, 白内 障発現の遅延するのを認めた。宮田 ${ }^{26)}$ は dinitrophenol 白内障の GSH との関係を調べた。Dinitrophenol は 瘦せ薬でこれを服用したヒトに進行性白内障の発生す るのを経験したことから本薬物が白内障との関倸で興 味を呼んだ。実験には幼若鶏が一番感受性が強いので 用いられる。成熟動物または哺乳動物などには実験が 不成功のことが多い。Dinitrophenol 注射後 1 時間前 後で水晶体洭濁が発現する。そして半日ないし1日で また透明の水晶体に回復する。この実験にて宮时は GSH 注射前処理が水晶体溷濁の予防に有効なことを 知り, かつ従来白内障治療薬として知られた V.C., 力 タリン、シネラリアとの比較実験を行なった。これ等 の薬剤はほとんど無効であった。Dinitrophenol 白内 障と老人性白内障と比較す心゙くもないが本白内障が可 逆的であることは興味深きことである。ヒトの白内障 にても水晶体蛋白の変性溷濁の場において特殊の場合 は可逆的変化もありらるし，また GSH 適用によりさ らに効果的であることも十分想像出来る。

教室におけるこれ等 GSH と水晶体特に白内障との 関係の研究は主として GSH を中心としたものであっ て白内障全般の研究としては実に九牛の一毛に過ぎな い。このほか実験的白内障は霆㧘白内障,放射エネルギ 一白内障, ナフタリン，エルゴチン，内分泌腺（甲状 腺, 副甲宊腺, 皮膚病) など数多くの報告があるが， 老人性白内障を余すところなく説明することは到底困 難である。

\section{9. 白内障の治療}

白内障の本態については未解決の点が多い。先天性 白内障はしばらく論外とし，最も多くかつ進行性であ るのは老人性白内障である。この白内障の経過は一般 に長くまた不規則であるので良来薬物療法が失敗した ことが多い。それに白内障のごとく变性蛋白が回復す ることについても疑問を持たれていた。しかし宮田の 実験のごとくdinitrophenol 白内障の予防に GSH が 
$-10-(82)$

有効であることは白内障の薬物療法に曙光をえたとい わ权ばならない。また田野皇)の糖尿病白内障にて糖尿 治療の結果水晶体の透明化した報告がある。薬物療法 の可能性を物語るものである。

そこで藠物療法の歴史をみるとかなり古くから行な われたらしい。それ等は必ずしも理論に立脚したもの ではなく, 経験によって出発したものもある。

1) 沃度剛: Gondret (1828) がはじめて沃度加里 の内服を白内障に試みたという。その後数多くの人々 により沃度加里の内服, 点眼, 眼浴, あるいはイオン トフォレーゼなどが行なわれ, 老人性白内障の進行防 止あるいは治療に有効無効が論ぜられてきた。木原 ${ }^{13)}$ は水晶体の新陳代謝を測定し少量の沃度加里は新陳代 謝を盛んにするがこれは沃度イオンのためでなく加里 イオンによるとした。この実験と白内障との関倸は結 びっくかどうか不明である。近年においては沃度加里 の使用はまれになってきたようである。

2) ビタミンC：水晶体は多量のビタミンCを含有 し白内障になるとそれは減少あるいは消失することが 知られている。また白内障実験動物でビタミンC 久学 状態において実験すると白内障の発現率の多いことも 分っている。そこで白内障の予防治療にこれが使用さ れ沢山の報告がみられる。しかし壊血病患者に白内障 の発生をみることはないし, 水晶体溷濁との間に有意 の相関はみられないようである。

3) パロチン：唾液腺ホルモンとしてパロチンが抽 出され，中胚葉性疾患に有効であるとの報告が多い。 はじめに萩原, 光星 ${ }^{14)} に よ り$ 有効例が報告された。こ れ等注老人性白内障にパロチン $3 \mathrm{mg}$ を週 2 回筋注し 一部のものには結膜下注射を行なって有効例が多いと した。その理論として中胚葉に由来する水晶体䡬の異 常透過性に対して調節的に作用し水晶体の新陳代謝に 好影響を与えるだろうと推論した。

その後多くの支持をえて注射, 内服として使用され ている。水晶体培は外覔葉由来の組織であると多くに 承認されているが，また一部中胚葉性のものであって も，白内障の発生を説明するには不十分とも思われる。

4) シネラリア：アメリカで発売された白内障の治 療薬である。これは菊科植物の cineraria martima の 全草の抽出液である。アメリカにおいてては民間薬のよ うな薬剤として使用され，報告は余り見当らない。日 本では藤山 ${ }^{15}$ が外傷性白内障 2 例に使用して前房にで た水晶体皮質の吸収がきわめて良好であったと報告し た。以来多くのヒトにより外傷性白内障に使用され，
有効例が多い。ついで外傷性白内障のほか, 佐伯 ${ }^{16)}$ は 老人性白内障にも使用し多少の効果があったという。 シネラリアの有効成分は不明である。藤山も最初の報 告でその症例の水晶体皮質の吸収は自然治癒であった かも知孔ないと報告しているが，その後の追試者はい ずれも有効であるとの報告が多い。Sinerariaに関し ては有効成分の分析が必要ではあるまいか。

5） カタリン: 荻野 ${ }^{17}$ はキノン体が水晶体に到達す ると, 水晶体の可溶性蛋白を変化させ不溶性にするこ とが白内障であるとし，水晶体に多量存在する V.C., GSH などはキノン体を還元無瑇化し，また水晶体蛋白 の変性防止にも有意義であるとした。しかし生体にお けるキノン体の形成機序ならびに蛋白変性の問題など は将来の研究に俟つと報告した。そしてこの学説のう えに立って， $\mathrm{C}_{16} \mathrm{H}_{8} \mathrm{~N}_{2} \mathrm{O}_{5}$ なる化合物をつくり catalin と命名し白内障の予防治療に応用した。カタリンはキ ノン体よりは水晶体蛋白と親和性が強くかつその結合 は水晶体蛋白を溷濁させないという。荻野はカタリン を注射ならびに点眼して老人性白内障 144 眼について $1 \sim 2$ 年の経過中進行停止 90 腿, 視力やや改善 41 眼, やや悪化 15 眼の成績であったと報告した。カタリン の使用は多くの支持を受け有効例の報告は数多い。

6） GSH：V.C. とともに GSH は水晶体に最も多 く含有され，水晶体溷濁との関倸は古くから注目され たことであった。しかし V.C. はさきに述べたとおり 水晶体発生との間に有意の相関を認めがたいようで, 白内障治療薬としても一応下火になった。水晶体蛋白 の 1 つである $\beta$ クリスタリンは $\mathrm{SH}$-蛋白であるが， 白内障が進行するとともに蛋白 SH も GSH も同様に 減少, 消失するので水晶体の溷濁と $\mathrm{SH}$ の消失は早く より多くの注目するところであった。われわれは視器 の GSH の研究中 GSH を多量試用する機会をえたの で各種眼疾患の治療に応用した (GSH は山之内製薬に てタチオンとして発売されている)。

はじめに小口ら ${ }^{18)}$ は GSH の沎膜抢よび白内障につ いての効果を報告した。すなわち, 老人性白内障 62 眼 に注射点眼併用療法定行ない, 有効 $59.03 \%$, 不変 30.64\%，無効9.67\%であった。そして1日 100mg 注 射量は多量注射の方が望ましいとした。

神鳥ら ${ }^{19}$ は各種疾患にタチオン注射の使用経験の中 で老人性白内障 6 例についていずれも有効であったと 述べた。ついで神鳥ら ${ }^{20}$ はタチオンの点眼薬のみによ る効果を老.人性白内障 24 例, 外傷 1 例, 糖尿性白内障 10 例に検した。約半年後の経過で有効例が多く初期白 
内障の薬物療法として大いに期待出来ると述べた。関 21) は老人性白内障 20 名 39 眼にカタリン点眼, V.C. の補給タチオン $100 \mathrm{mg}$ を隔日注射し約 3 カ月の経過 にて初発白内障にては満足の結果をえた。関は白内障 の成熟するまで放置することなく, 薬物療法の恩恵に 浴寸べき旨の意見を述べた。GSH の白内障に対する 応用は期待される点が多い。

7）その他：ホルモン剤としてェナルモン，才バホ ルモン, 動物水晶体蛋白の内服, 漢方薬, スルファミ ン剂種々のものが試用されたが，このうち将来研究の 対象となるものは少ないようである。

\section{文献}

1) Goldsmith, J. : Original studies on the internal dynamics of the intracapsular cataract extraction. New York Journal of Medicine, 43, No.18, 1943.

2) Becker, O. : Pathologie des Linsensystem. Graefe Sämisch. Handbuch d. Ophth , 5. 157.

3) Greef, R. : Die pathologische Anatomie des Auges.

4) v.Kittel, : Erworbene Linsen Kolobome. Kl. Monatb!. f. Augh., 136, 540. 1960.

5）水尾源太郎：稀有なる眼の先天異常及びての成立に関 する学説について. 日眼, 10,323, 1906.

6）酒井信一：先天性水晶体欠損症の 2 例. 眼臨, 48, 11, 1954.

7) 藤井清信 : 先天性水晶体偏位症の一例. 眼臨, 17,84 , 1922.

8）小林紹章: 水晶体発育障碍の 2 例. 腿臨, 55, 343, 1961.

9）赤羽純正：ナフタリン白内障の GSH の消長. 第 435 回 東京腿科集談会.
( 83$)-11-$

10）小口昌关，樋田敏夫，清水由規，清水公政：白内障の 成因とチン氏帯の関係. 日眼, 67，768，1963.

11）小口昌美, 桶田敏夫, 平林邦夫：再び水晶体の純チン 氏带栄賈説を論ず。日眼，68，1126，1964.

12）田野：全身治療により軽快せる糖尿病性白内障兼遠視. 綜眼, 39, 449, 1944 46.

13）木原幸雄：水晶体の新陳代謝. 日眼，37，2135，1933.

14）萩原 朗, 光星寿美子：初発白内障に対するパロチン の臨床応用. 眼臨, 49, 175, 1955.

15）藤山英寿：Succus cineraria martima点眼による外 傷性白内障治療の 2 例. 臨腿, 8, 1107, 1954.

16）佐伯 譲: Succus cineraria martimaの点眼による 老人性白内障治療経験. 臨眼, 12, 587, 1958.

17）荻野周三 : 眼の臨床生化学.

18）小口昌美，清水由規，桶田敏夫，内山幸昌，河瀬澄男， 関 公：眼疾患に対するグルタチオンの効果。臨眼, 20, $285,1966$.

19）神鳥文雄, 福永, 山本, 野村: 眼科領域における夕千 オンの使用経験。第70回日眼統会.

20）神鳥文雄：白内障に対するタチオン点眼液の効果。日 眼, 71，689，1967.

21）関 洲一：グルタチオン注射による白内障の治療経験. 臨眼, 21, 767, 1967.

22）小口昌美, 清水由規：グルタチオンの新検出法。綜合 医学, 19, 12. 1962.

23）小口昌美, 樋田敏夫, 清水由規, 清水公政 : 眼球のグ ルタチオンの分布. 日眼, 66, 1488, 1962.

24）内山幸昌: 実験的ガラクトース白内障の研究. 日眼, 70. $1118,1966$.

25）星 普雄: X線白内障と GSH の関係. 第454回東京 眼科集談会.

26）宮田昭男：Dinitro phenol 白内障と GSH. 第4 439 回東 京眼科集談会. Dinitrophenol 白内障に対する各種薬 剂の効果. 第448 回東京眼科集談会. 実験的 Dinitrophenol 白内障の研究. 第 449 回東京眼科集談会.

（受付：1968 年2月 5 日） 